\title{
Changes in DNA fragmentation during sperm preparation for ICSI over time
}

\section{Alterações na fragmentação do DNA durante a preparação de esperma para ICSI ao longo do tempo}

\author{
MSc. Cristian Alvarez Sedó*1; BS. Miguel Ángel Barros*2; MSc. Heydy Uriondo Boudri*3; MD. Natalia Rougier*4 \\ MD. Sergio Papier*5; MSc. Florencia Nodar*6

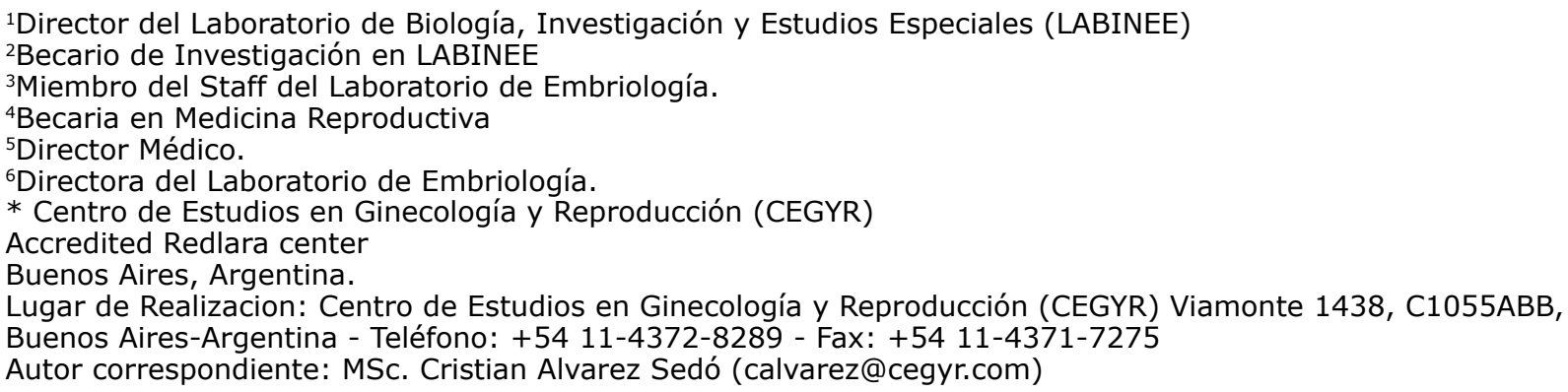

\section{ABSTRACT}

Objective: To compare the DNA fragmentation of semen samples established by TUNEL after incubation in PVP at different time periods and temperature conditions.

Methods: Semen analysis and DNA fragmentation assays (TUNEL) were performed. Two groups were established: (A) Normal TUNEL Q20\% and (B) Abnormal TUNEL $>20 \%$. TUNEL was performed in: neat (TO), post-gradient/swim-up (TG/TS), 1 hour post-gradient/swim-up (TG1/TS1), and 2 hours post-gradient/swim-up (TG2/TS2) samples at room temperature or $37^{\circ} \mathrm{C}$, and in TG2/TS2 samples after 30,60 , and 90 minutes of incubation in PVP at $37^{\circ} \mathrm{C}$. TG and TS (RT and $37^{\circ} \mathrm{C}$ ) aliquots after 24 hours of incubation were assessed.

Results: TUNEL levels were significantly reduced after gradient and swim-up separation relative to neat values. After gradient, in group A, TUNEL levels were significantly higher in the TG2-90 hours at RT and TG2-30 at $37^{\circ} \mathrm{C}$. Samples did not reach abnormal levels. In group $B$, TUNEL levels were significantly higher in TG2+60 at RT and $\mathrm{TG} 2-30$ at $37^{\circ} \mathrm{C}$. After swim-up, in group A, TUNEL levels were significantly higher in TS2-30 hours at RT and $37^{\circ} \mathrm{C}$. In group $\mathrm{B}$, TUNEL levels were significantly higher in TS2 at RT and $37^{\circ} \mathrm{C}$.

Conclusions: Sperm DNA fragmentation significantly decreased after centrifugation gradient and swim-up, regardless of the initial levels of the sample. Samples with TUNEL $>20 \%$ were more susceptible to a significant increase in DNA fragmentation over time. Samples after gradient and incubated at room temperature were lesser susceptible to a significant increase in DNA fragmentation. These data may be relevant for sperm preparation for ICSI.

Key words: DNA fragmentation, TUNEL, ICSI, PVP.

\section{RESUMO}

Objetivo: comparar a fragmentação do DNA das amostras seminais estabelecidas pelo TUNEL após incubação em PVP em diferentes períodos de tempo e condições de temperatura.

Métodos: análise de sêmen e ensaios de fragmentação de DNA (TUNEL) geraram 2 grupos: (A) normal, TUNEL $<20 \%$ e (B) Anormal, TUNEL $>20 \%$. TUNEL foi realizado: puro (TO), post-gradient/swim-up (TG / TS), 1 hora post-gradient/swim-up (TG1/TS1), e 2 horas post-gradient/swim-up (TG2 / TS2), amostras à temperatura ambiente ou a $37^{\circ} \mathrm{C}$, e em TG2/TS2, amostras após 30, 60 , e 90 minutos de incubação em PVP a $37^{\circ} \mathrm{C}$. Alíquotas TG e TS (RT e $37^{\circ} \mathrm{C}$ ) foram avaliadas após 24 horas de incubação.

Resultados: Os níveis de TUNEL foram significativamente reduzidos após separação por gradiente e swim-up em relação aos valores puros. Depois do gradiente, no grupo $A$, os níveis TUNEL foram significativamente mais elevados no TG2-90horas ambiente e TG2-30 a $37^{\circ} \mathrm{C}$. As amostras não atingiram níveis anormais. No grupo $B$, os níveis TUNEL foram significativamente maiores no TG2+ 60 ambiente e TG2-30 a $37^{\circ} \mathrm{C}$. Após swim-up, no grupo $A$, os níveis TUNEL foram significativamente maiores no TS2-30 horas ambiente e $37^{\circ} \mathrm{C}$. No grupo $\mathrm{B}$, os níveis de TUNEL foram significativamente maiores no TS2 ambiente e $37^{\circ} \mathrm{C}$.

Conclusões: A fragmentação de DNA de esperma diminuiu significativamente após a centrifugação de gradiente e swim-up, independentemente dos níveis iniciais. As amostras TUNEL $>20 \%$ foram mais susceptíveis a um aumento significativo na fragmentação do DNA ao longo do tempo. Amostras pós gradiente e incubadas à tempe- 
ratura ambiente foram menos susceptíveis a um aumento significativo na fragmentação do DNA. Estes dados podem ser relevantes para a preparação de espermatozóides para ICSI.

Palavras-chave: fragmentação de DNA, TUNEL, ICSI, PVP.

\section{INTRODUCTION}

In the last decade, the evaluation of sperm DNA fragmentation has become more important as a method to assess semen quality. Several authors have reported a negative correlation between high DNA fragmentation levels and assisted reproductive technology (ART) outcomes (Lewis et al., 2008; Speyer et al., 2010; Simon et al., 2010; Steger et al., 2011). DNA fragmentation is considered an important predictor of reproductive outcomes in IVF treatments compared with other sperm characteristics, such as progressive motility (Simon \& Lewis, 2011).

Some reports have revealed that DNA fragmentation can undergo a significant increase with increased incubation times, and it has also been demonstrated that sperm from fertile males is more resistant to DNA fragmentation over time than sperm from infertile men. These reports have also demonstrated differences in DNA fragmentation dynamics based on the origin of the sample (i.e., fresh vs. frozen), showing that frozen samples presented greater DNA fragmentation in less time compared to fresh samples (Gosálvez et al., 2010; Gosálvez et al., 2011). ICSI (intracytoplasmic sperm injection) and IMSI (intracytoplasmic morphologically selected sperm injection) require the preselection of motile sperm, which can be accomplished using a double-layer centrifugation gradient. Motile spermatozoa obtained in the pellet are suspended in culture medium and stored for at least 2-3 hours. After this time (while oocytes are prepared for injection), motile spermatozoa are placed in PVP for approximately $0.5-1.5$ hours to slow their movement and perform sperm tail breakage to allow their selection for ICSI or IMSI.

Appropriate semen analysis is a mandatory practice in infertility clinics. Spermatozoa used for assisted reproductive technique (ART) are mostly prepared by density gradient centrifugation (DGC) or a swim-up method, both aiming to enrich mature, motile and morphologically normal spermatozoa. Some authors have reported that DNA Fragmentation levels should be better after gradient density centrifugation rather than swim-up technique. However, recently publications showed no significant differences between both techniques (Stevanato et al., 2008; Ricci et al., 2009; Zhang et al., 2011; Amiri et al., 2012).

As the main objective of this study, we tested whether in vitro incubation, which is routinely practiced in clinical andrology and embryology laboratories, affects sperm DNA integrity. Using fresh semen, we compared DNA fragmentation levels (TUNEL) between samples prepared by different methods and exposed to different incubation conditions.

\section{MATERIAL AND METHODS}

\section{Population}

Thirty four patients who were undergoing ART were selected for this study. Men with normal hormonal profi- les (FSH, LH, PRL, and testosterone), semen samples of more than $1 \mathrm{ml}$, and sperm concentrations higher than $5 \times 10^{6} / \mathrm{ml}$ were eligible for inclusion. Men with urogenital infections, varicocele and cryptorchidism were excluded. All procedures were performed at CEGYR (Reproductive Medicine) in Buenos Aires, Argentina from October 2012 to February 2013. Semen samples were donated for research with informed written consent by couples undergoing assisted reproduction procedures at CEGYR. This study was approved by the Internal Review Board and Ethics Committee of CEGYR. There is no conflict of interest at the present study.

\section{Semen samples preparation}

Samples were collected by masturbation after sexual abstinence for 2-4 days. After semen liquefaction (30-60 minutes), basic semen analysis was performed (motility, concentration and survival, morphology), and motile sperm were selected using a double-layer gradient (45$90 \%$ ) (Isolate, Irvine Scientific, CA, USA) according to the procedures established by the World Health Organization (2010). Isolated motile sperm was adjusted to a final concentration of $2 \times 10^{6}$.

DNA fragmentation (TUNEL) was assessed in neat (TO), post-gradient (TG), postswim-up (TS), $1 \mathrm{~h}$ post-gradient or swim-up (TG1-TS1), and $2 \mathrm{~h}$ post-gradient or swim-up (TG2-TS2) samples at room temperature (RT) or at $37^{\circ} \mathrm{C}$ in H-HTF (Modified Human Tubal Fluid) (Irvine Scientific, CA, USA). After this time (TG2 and TS2), samples were incubated in PVP (Irvine Scientific, CA, USA) under oil (Irvine Scientific, CA, USA) over an inverted microscope equipped with a heating plate $\left(37^{\circ} \mathrm{C}\right)$. Aliquots were taken at $0.5,1.0$, and 1.5 hours (TG2-30/TS2-30, TG2-60/ TS2-60, and TG2-90/TS2-90, respectively) for assays. For PVP fractions, sperm were carefully aspirated from the peripheral region. For each samples it was taken in consideration an aliquot (TG and TS at RT or $37^{\circ} \mathrm{C}$ ) after 24 hs. Figure 1 depicts the used experimental design in this study. Each semen sample

\section{Evaluation of DNA fragmentation (TUNEL)}

All fractions were fixed in $2 \%$ formaldehyde (Sigma, MO, USA) in 1X PBS (pH 7.4) (Gibco, Paisley, PA, USA) for at least 1 hour. Each sample was placed into one well of a multiwell (4-mm diameter) Teflon-printed slide (Electron Microscopy Sciences, PA, USA) and allowed to settle. After 2-3 hours, each well was washed with $1 X$ PBS (three times, 5 minutes each), and the cells were permeabilized with cold methanol (Merck, Germany). Prior to incubation with the TUNEL solution, each well was washed again with $1 X$ PBS. For each sample, one extra well was incubated with DNAse $(1 \mathrm{U} / \mathrm{ml}$ ) (Sigma, CA, USA) for 30 minutes at $37^{\circ} \mathrm{C}$ as a positive control, and the TUNEL "enzyme" solution was omitted from another well as a negative control. Then, all samples were incubated in TUNEL solution (ROCHE, Mannheim, Germany) for one hour at $37^{\circ} \mathrm{C}$. All samples were finally washed with $1 \mathrm{X}$ PBS (three times, 5 min each), and mounted in Vectashield $\mathrm{H}-1000$ medium (Vector Laboratories, CA, USA). A total of 500 spermatozoa were counted by fluorescence microscopy for each fraction. TUNEL staining was evaluated by fluorescence microscopy using a green filter (FITC, $488 \mathrm{~nm}$ ). Figure 2 shows light and dark field images of negative ("enzyme" of TUNEL solution omitted) (A, $\left.\mathbf{A}^{\prime}, \mathbf{A}^{\prime \prime}\right)$ and positive controls (incubated in DNAse such that all spermatozoa have green head fluo- 
rescence) (B, B', B'). Only complete spermatozoa (Fig 1. C, $\mathbf{C}^{\prime}$, arrow) were considered for percentage estimates; heads without tails were not considered (Fig 1. C, C', C', arrowhead).

\section{Statistics}

The Student's $t$-test was used for between-group comparisons, and the Mann-Whitney $U$-test was used to assess homogeneity. Differences were considered significant when $\mathrm{p}<0.05$. MedCalc 12.4 software (Belgium) was used for the statistical analysis.

\section{RESULTS}

To permit a more accurate analysis and interpretation of the results, the population was separated into two groups: patients with TO TUNEL $<20 \%$ (GROUP A) and those with TO TÚNEL > 20\% (GROUP B).

The sperm characteristics of both populations are described in Table 1 and 2. Because volume and concentration were used as inclusion criteria, no significant difference was found in these parameters. However, significant differences were observed in age, morphology (Kruger) and motility $(\mathrm{p}<0.05)$.

The average TUNEL levels decreased significantly after centrifugation through a double-layer gradient (TO vs. TG) and swim-up (TO vs. TS), regardless of the initial TUNEL status of the sample. At room temperature, TO vs. TG was $18.7 \pm 5.1$ vs. $8.8 \pm 4.9$ in group $A$ and $34.6 \pm$ 5.4 vs. $25.9 \pm 5.0$ in group $B$, and T0 vs. TS was $18.7 \pm$ 5.1 vs. $12.1 \pm 4.0$ in group $A$ and $34.6 \pm 5.4$ vs. $26.7 \pm$ 4.4 in group $B$ (Figure 4, $* p<0.05$ ). This feature can be clearly distinguished in Figure 3 (A vs. B). Interestingly, TG was significantly lower than TS in group $A$ but not in group B (Figure $\mathbf{4}, * * p<\mathbf{0 . 0 5}$ ).

After the gradient centrifugation or swim-up, motile sperm were incubated at room temperature or $37^{\circ} \mathrm{C}$ for 2 hours in culture medium. During this period, when gradient was performed, the TUNEL levels within each group remained stable at room temperature (group A: $8.8 \pm 4.9$ vs. $10.4 \pm 5.3$; group B: $25.9 \pm 5.0$ vs. 28.3 \pm 5.4 ) and at $37^{\circ} \mathrm{C}$ (group A: $8.8 \pm 4.9$ vs. $11.3 \pm 5.9$; group B: $25.9 \pm 5.0$ vs. $29.1 \pm 5.7$ (Fig. 5). Likewise, when swim-up was addressed, the TUNEL levels within each group remained stable at room temperature (group A: $12.1 \pm 4.0$ vs. $14.6 \pm 4.7$; group B: $26.7 \pm 4.4$ vs.

Table 1. Sperm parameters in total population.

\begin{tabular}{lcc}
\hline $\mathrm{N}=34$ & $\mathrm{X}$ & $\mathrm{SD}$ \\
\hline Age & 39,5 & 5,3 \\
\hline Kruger $(\%)$ & 8,4 & 4,1 \\
\hline Volume $(\mathrm{ml}-)$ & 2,9 & 1,1 \\
\hline Concentration $(\times 106 / \mathrm{ml})$ & 62,4 & 39,3 \\
\hline$\%$ Motility $(\mathrm{A}+\mathrm{B})$ & 42,5 & 14,1 \\
\hline
\end{tabular}

Table 2. Sperm parameters values between group $A$ and $B$.

\begin{tabular}{lccc}
\hline & $\begin{array}{c}\text { TUNEL }<20 \% \\
(\mathrm{~A})\end{array}$ & $\begin{array}{c}\text { TUNEL } \geq 20 \% \\
(\mathrm{~B})\end{array}$ & \\
\hline $\mathrm{N}$ & 20 & 14 & $p$ \\
\hline Age & $37.8 \pm 4.3$ & $41.9 \pm 5.9$ & 0.02 \\
\hline Kruger (\%) & $9.5 \pm 4.4$ & $6.6 \pm 3.2$ & 0.04 \\
\hline Volume (ml-) & $2.6 \pm 0.9$ & $3.1 \pm 1.2$ & $\mathrm{NS}$ \\
\hline $\begin{array}{l}\text { Concentration } \\
(\times 106 / m \mathrm{~m})\end{array}$ & $72.4 \pm 40.3$ & $48.1 \pm 34.3$ & $\mathrm{NS}$ \\
\hline$\%$ Motility $(\mathrm{A}+\mathrm{B})$ & $48.3 \pm 13.7$ & $34.3 \pm 10.4$ & 0.02 \\
\hline
\end{tabular}

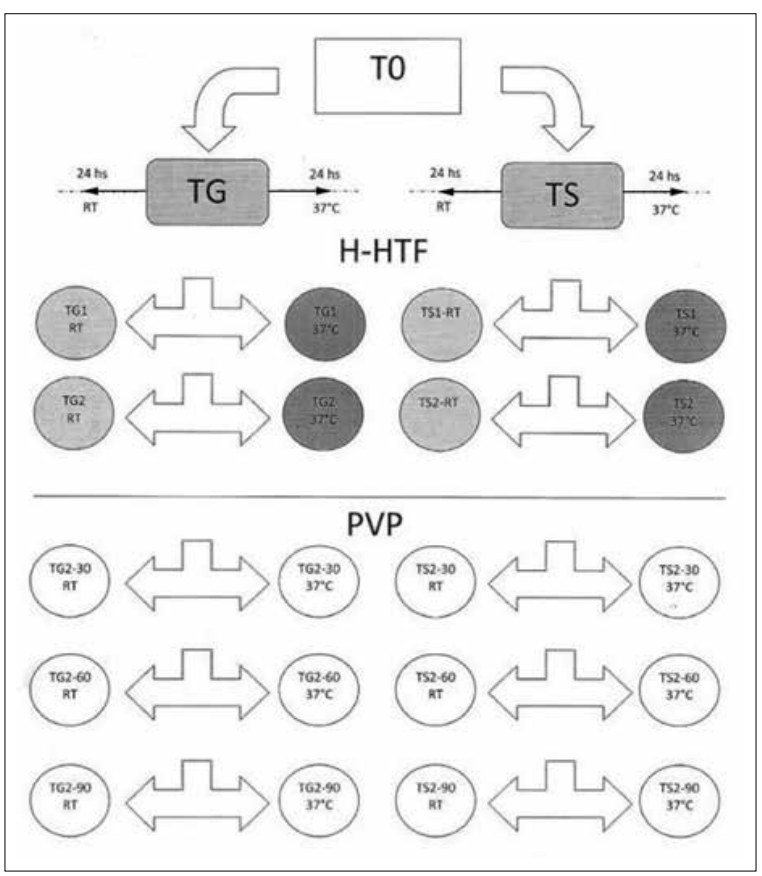

Figure 1. Flux diagram of the experimental design. $\mathrm{T} 0=$ neat sample, TG= post gradient fraction, $\mathrm{TS}=$ post swim-up fraction, TG 1 and TS1 $=1$ hour post TG and TS, TG 2 and TS $2=2$ hours post TG and TS, TG2-30/TS2-30, TG2-60/TS2-60, TG2-90/ TS2-90 $=30,60$ and 90 post TG2/TS2, respectively. TG24-RT, TG24-37 ${ }^{\circ} \mathrm{C}$, TS24-RT and TS24-37 ${ }^{\circ} \mathrm{C}$ corresponds to TG and TS after 24 hours of incubation at RT or $37^{\circ} \mathrm{C}$.
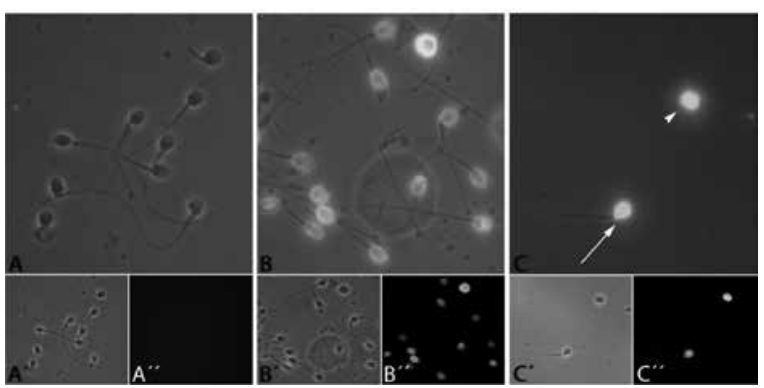

Figure 2. TUNEL assay. The negative control was performed by omitting the "enzyme" solution (phase contrast $\left(A^{\prime}\right)$ under green fluorescence $(A)$ and $A^{\prime \prime}$ dark field + fluorescence). A DNAse-treated sample was used as a positive control ( $B$, green fluorescence $-100 \%$ of positive cells, $B^{\prime}$ phase contrast and $B^{\prime \prime}$ dark field + fluorescence). Only complete spermatozoa (arrow) were considered in the evaluation of TUNEL; sperm heads without tails were not counted for this purpose (Fig C, arrowhead).

$30.4 \pm 4.3$ ) and at $37^{\circ} \mathrm{C}$ (group A: $12.1 \pm 4.0$ vs. $15.8 \pm$ 5.0; group B: $26.7 \pm 4.4$ vs. $31.5 \pm 4.4$ (Fig. 5).

Analyzing gradient samples, in patients with TUNEL < $20 \%$, we observed a significant increase of DNA fragmentation at TG2-90 and TG2-30 for RT and $37^{\circ} \mathrm{C}$, respectively, and DNA fragmentation levels were not considered altered $(<20 \%)$ in either case (Fig. 5, $* \mathbf{p}<\mathbf{0 . 0 5})$. Moreover, in patients with TÚNEL $>20 \%$, we observed a significant increase in DNA fragmentation at TG2-60 and TG2-30 for $\mathrm{RT}$ and $37^{\circ} \mathrm{C}$, respectively (Fig. 5, $* \mathbf{p}<\mathbf{0 . 0 5}$ ). Sperm motility between TG and TG2 (RT and $37^{\circ} \mathrm{C}$ ) didn 't change during the incubation time (data not shown). Considering swim-up samples, in patients with TUNEL < 

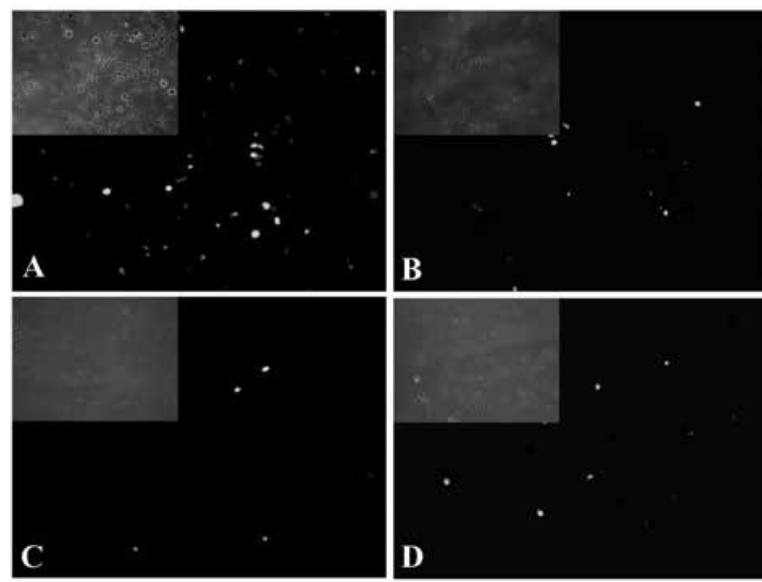

Figure 3. Example of sperm DNA fragmentation dynamics at the first two hours of incubation after gradient at RT. TO (A), TG (B), TG1 (C), TG2 (D). Images of green fluorescence/dark field and phase contrast microscopy (insets) were captured.

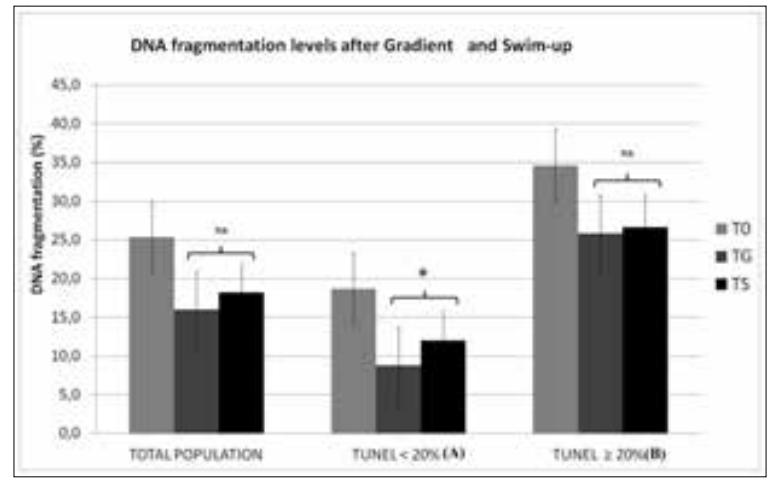

Figure 4. DNA fragmentation levels after gradient and swim-up in total population, group $A$ and $B$.

$* p<0.05$

$\mathrm{NS}=$ no significant difference

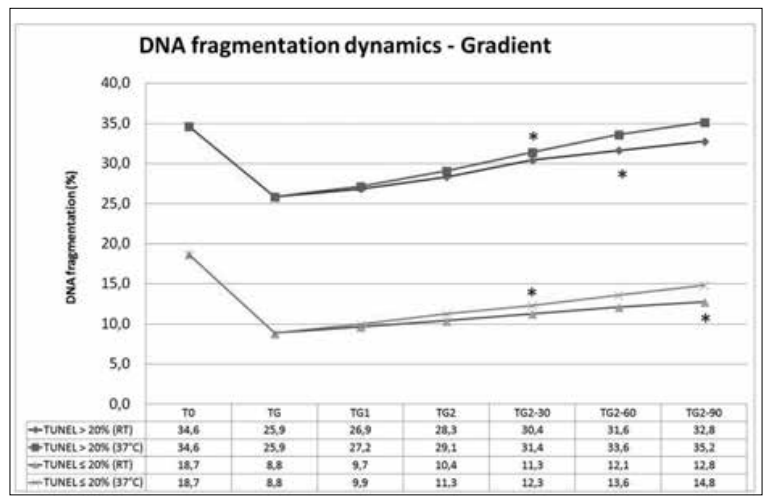

Figure 5. DNA fragmentation dynamics after gradient in groups $A$ and $B$.

$* p<0.05$

$20 \%$, we observed a significant increase of DNA fragmentation at TS2-30 and TS2 for RT and $37^{\circ} \mathrm{C}$, respectively (Fig. 6, * p $<$ 0.05). In patients with TÚNEL $\geq 20 \%$, we observed a significant increase in DNA fragmentation at TS2 for both fractions (RT and $37^{\circ} \mathrm{C}$ ) (Fig. 6, $* \mathbf{p}<\mathbf{0 . 0 5}$ ). Sperm motility between TG and TG2 (RT and $37^{\circ} \mathrm{C}$ ) didn 't change during the

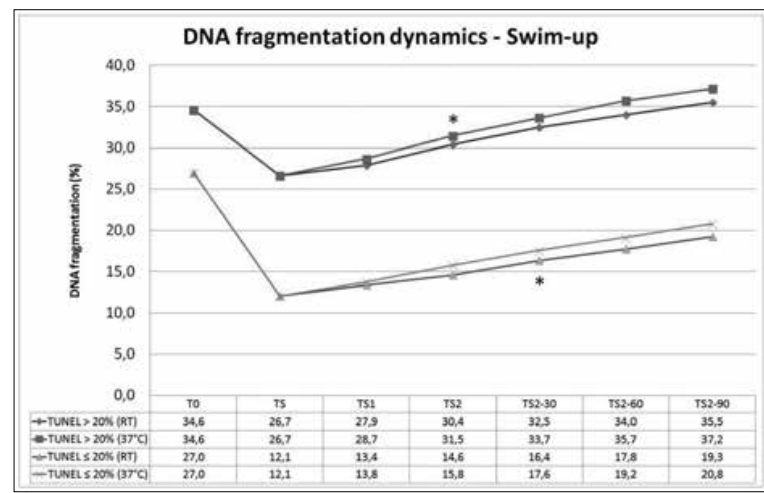

Figure 6. DNA fragmentation dynamics after swim-up in groups $A$ and $B$.

$* p<0.05$

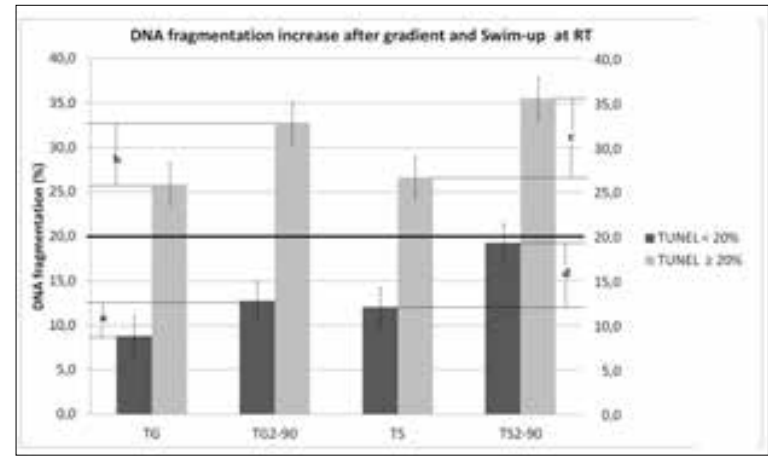

Figure 7. DNA fragmentation increase after gradient and swim-up in groups $A$ and $B$ at room temperature. $a=$ difference between TG2-90/TG (group A) $\mathrm{b}=$ difference between TG2-90/TG (group B) $\mathrm{C}=$ difference between TS2-90/TS (group A) $\mathrm{d}=$ difference between TS2-90/TS (group B)

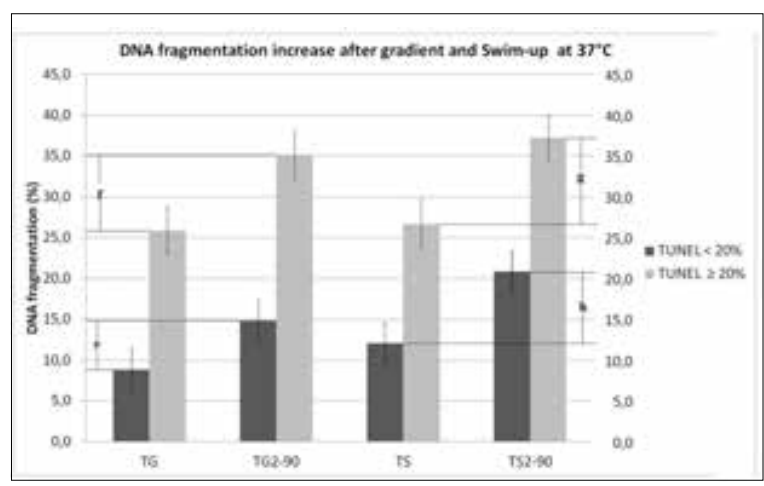

Figure 8. DNA fragmentation increase after gradient and swim-up in groups $A$ and $B$ at $37^{\circ} \mathrm{C}$

$\mathrm{e}=$ difference between TG2-90/TG (group A)

$\mathrm{f}=$ difference between TG2-90/TG (group B)

$\mathrm{g}=$ difference between TS2-90/TS (group A)

$\mathrm{h}=$ difference between TS2-90/TS (group B)

incubation time (data not shown).

The increase of DNA fragmentation levels between TG and TS in compare with the end point of this experience (TG2 or S2-90, almost 4 hours after) was: At room temperature, in group $A 4 \%$ (a) and $7.2 \%$ (d) for gradient and swim-up, respectively; in group B $6.9 \%$ (b) and $8.8 \%$ (c) for gradient and swim-up, respectively (Fig. 7). At $37^{\circ} \mathrm{C}$, in group $A$ 6\% (e) and $8.7 \%(\mathrm{~h})$ for gradient and swim-up, respectively; in group B $9.3 \%$ (f) and $10.5 \%(g)$ for 


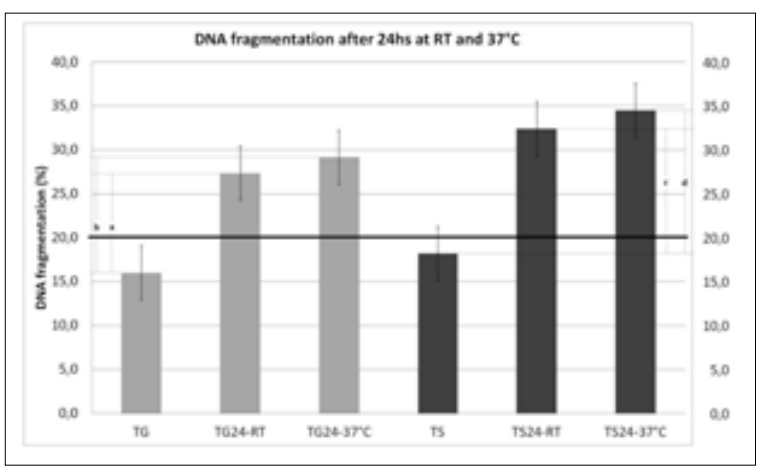

Figure 9. DNA fragmentation increase after gradient and swim-up at room temperature and $37^{\circ} \mathrm{C}$ after 24 hours. $\mathrm{a}=$ difference between TG24-RT/TG

$\mathrm{b}=$ difference between $\mathrm{TG} 24-37^{\circ} \mathrm{C} / \mathrm{TG}$

$\mathrm{c}=$ difference between TS24-RT/TS

$\mathrm{d}=$ difference between $\mathrm{TS} 24-37^{\circ} \mathrm{C} / \mathrm{TS}$

gradient and swim-up, respectively (Fig. 8).

Considering the entire population the levels of DNA fragmentation after 24 hours of incubation was assessed. When gradient was performed, the increase of DNA fragmentation was $11.4 \%$ (a) (RT) and $13.2 \%$ (b) $\left(37^{\circ} \mathrm{C}\right)$. When swim-up was carried out the increase of DNA fragmentation was $15.8 \%$ (c) (RT) and $16.3 \%\left(37^{\circ} \mathrm{C}\right.$ ) (Fig. 9).

\section{DISCUSSION}

Our results show that DNA damage increases more rapidly over sample preparation time in semen samples with $>20 \%$ DNA fragmentation than in samples with $<20 \%$ DNA fragmentation, and this feature increases faster at $37^{\circ} \mathrm{C}$ rather than $\mathrm{RT}$.

During sperm preparation for ART procedures (ICSI or IMSI), it is important to consider sperm DNA fragmentation prior to the treatment. High values can significantly affect the reproductive outcomes. The most common sperm selection methods used in ART are "swim-up" and double-layer gradient centrifugation methods (Henkel \& Schill, 2003). The swim-up technique is based on the ascending capacity of the sperm, i.e., their progressive motility, and the gradient technique is based on the migration of mature motile sperm against centrifugal force. The swim-up technique is useful in sperm samples with good concentration and motility. In samples with high DNA fragmentation, the double-layer gradient technique has been proven to significantly reduce DNA damage compared to the swim-up method. In addition, gradient centrifugation could also improve some sperm parameters such as survival time, morphology, and others (Matsuura et al., 2010; Zhang et al., 2011; Allamaneni et al., 2005, Amiri et al., 2012). However, other groups published that there is no different between both techniques (Ricci et al., 2009), more over other authors declare no difference between gradient and neat samples (Stevanato et al., 2008).

Therefore, we chose to perform the assay using the double-layer gradient technique and swim-up techniques to compare this event occurrence. As our previous report, the present results confirm that the use of gradient centrifugation significantly reduces DNA fragmentation levels (Rougier et al., 2013). At the present study swim-up technique also significantly improves DNA fragmentation levels in relation with the neat sample. However, considering the whole population, there was no differen- ce between gradient vs. swim-up. This difference was inclined in favor of the gradient when we analyzed only patients with DNA fragmentation levels $<20 \%$. We assumed that this could be related that these samples had better sperm quality, mainly motility, morphology and chromatin conformation.

This experiment reproduces the events that occur prior to ICSI or IMSI, and consider different conditions, such us room temperature or $37^{\circ} \mathrm{C}$ incubation. The present study only omits sperm micromanipulation and immobilization by tail breakage. Our aim was to evaluate when a significant increase of sperm DNA fragmentation takes place after gradient centrifugation (TG) or swim-up (TS), to improve and/or adjust the processing time used for this type of sample. In normal samples (TUNEL $<20 \%$ ), it was observed that TUNEL levels increased significantly after TG2-90 at RT or $37^{\circ} \mathrm{C}$, which represents a total of 3 and half hours (after gradient), however for swim-up fractions TUNEL levels significantly increased after TS2-30 at RT or $37^{\circ} \mathrm{C}$. No samples reached pathological levels during the indicated time; therefore, in sperm samples with normal TUNEL, it would be acceptable to wait at least 3.5 hs before the injection. In contrast, samples with abnormal initial TÚNEL values (> 20\%) exhibited a significant increase after TG2-60 at RT and TG2-30 at $37^{\circ} \mathrm{C}, 3$ and 3.5 hours post-gradient and swim-up, respectively. Consequently, it would be inappropriate to process these samples for a period longer than 3 hours and $37^{\circ} \mathrm{C}$. The sperm in group $B$ had worse quality, but the increase in DNA damage occurred only half an hour sooner in group $B$ than in group $A$ at $R T$, but one hour sooner at $37^{\circ} \mathrm{C}$. However, we found greater differences after longer time periods ( $24 \mathrm{hrs}$ ) for both techniques and incubation conditions (RT or $37^{\circ} \mathrm{C}$ ) in relation to TG or TS, but there was no difference between TG24RT and TG24-37 ${ }^{\circ} \mathrm{C}$ and TS24-RT and TS24-37 ${ }^{\circ} \mathrm{C}$. It is important to highlight that the highest level of DNA fragmentation was $34.5 \pm 9.5$ after 24 hours of incubation at $37^{\circ} \mathrm{C}$ (swim-up). It has been reported that DNA fragmentation may be associated with sperm apoptosis events (Wu et al., 2009; Sakkas et al, 2002, 2003; Oehninger et al., 2003; Singh et al., 2003; Moustafa et al., 2004). There is a relationship between increased reactive oxygen species (ROS) and apoptosis with consequent sperm DNA damage. Oxidative stress occurs when the amount of ROS exceeds the antioxidant capacity of the seminal plasma. Sperm are particularly susceptible to damage induced by ROS. These molecules cause injury by attacking the sperm plasma membranes, which contain large amounts of polyunsaturated fatty acids. Additionally, sperm cytoplasm contains low concentrations of reducing enzymes and apparently no mechanisms to repair DNA damage (Saleh \& Agarwal, 2002). DNA damage and ROS production can be clearly distinguished in the sperm of patients who are $>40-45$ years old, and these events can also induce a gradual decrease in sperm motility. In the present study, patients from group B were significantly older and had significantly diminished sperm motility compared with the patients from group A (Table 2). These factors could explain why the patients in group $B$ have an increased susceptibility to DNA damage.

The amount of DNA fragmentation at a time close to 4 hours TG2-90-TS2-90 did not exceed $4 \%$ and $7.2 \%$ in relation to TG, for group A at RT. Moreover, DNA fragmentation increase was $6 \%$ and $8.7 \%$ for gradient and swim-up, respectively $\left(37^{\circ} \mathrm{C}\right)$. In group $\mathrm{B}, 6.9 \%$ and $8.8 \%$ for gradient and swim-up, respectively (RT); likewise, $9.3 \%$ 
and $10.5 \%$ for gradient and swim-up, respectively $\left(37^{\circ} \mathrm{C}\right)$. This finding is contradictory to results reported by other authors, who observed an increase of $>30 \%$ at the same time period in infertile patients. However, the authors did not clarify if the study was performed in neat or processed samples. Those studies used the SCD (sperm chromatin dispersion) test to assay DNA fragmentation (Gosalvez et al., 2011). However, SCD and TUNEL results have been reported to have a high correlation $(R=0.9)$ in both fertile and infertile men (Chohan et al., 2006). There is no doubt that an increase in DNA damage occurs over time, but in our experience, the levels of damage do not increase more than $10.5 \%$ in four hours. We found a $16.3 \%$ of DNA fragmentation increase after 24 hours of incubation; however, these incubation periods are far beyond the usual sperm-processing time involved in ART. Accordingly to our results, Matsuura et al. (2010) and Amiri et al. (2012) proved that gradient and RT incubation could be a better sperm selection and condition to avoid DNA fragmentation increase during sperm preparation for ICSI.

Finally, excessive time spent on sperm preparation influences DNA damage levels; therefore, in patients with DNA fragmentation $\geq 20 \%$, it is especially important to minimize the processing time before ICSI or IMSI. Sperm in this subgroup seem to deteriorate more rapidly over time. Finally, follow-up studies should be performed to confirm that our results are correlated to ART outcomes, especially live birth rates.

\section{CONCLUSIONS}

Sperm DNA fragmentation significantly decreased after centrifugation gradient and swim-up, regardless of the initial levels of the sample. Samples with TUNEL $\geq 20 \%$ were more susceptible to a significant increase in DNA fragmentation over time. Samples after gradient and incubated at room temperature were lesser susceptible to a significant increase in DNA fragmentation. These data may be relevant for sperm preparation for ICSI.

\section{REFERENCES}

Allamaneni SS, Agarwal A, Rama S, and col. Comparative study on density gradients and swim-up preparation techniques utilizing neat and cryopreserved spermatozoa. Asian J Androl; 7(1) 2005:86-92.

Amiri I, Ghorbani M, Heshmati S. Comparison of the DNA Fragmentation and the Sperm Parameters after Processing by the Density Gradient and the Swim up Methods. J Clin Diagn Res. 2012; 6(9):1451-3.

Chohan KR, Griffin JT, Lafromboise M, and col. Comparison of chromatin assays for DNA fragmentation evaluation in human sperm. J Androl 2006; 27(1):53-9.

Gosálvez J, de la Torre J, López-Fernández C, and col. DNA fragmentation dynamics in fresh versus frozen thawed plus gradient-isolated human spermatozoa. Syst Biol Reprod Med 2010; 56(1):27-36.

Gosálvez J, Núñez R, Fernández JL, and col. Dynamics of sperm DNA damage in fresh versus frozen-thawed and gradient processed ejaculates in human donors. Andrologia 2011 43(6):373-7.
Henkel RR, Schill WB.Sperm preparation for ART. Reprod Biol Endocrinol 2003; 14(1):108.

Lewis S.E, Agbaje I, Alvarez J. Sperm DNA tests as useful adjuncts to semen analysis. Syst Biol Reprod Med 2008: 54 (3):111-25.

Matsuura R, Takeuchi T, Yoshida A. Preparation and incubation conditions affect the DNA integrity of ejaculated human spermatozoa. Asian J Androl 2010; 12(5):753-9.

Moustafa MH, Sharma RK, Thornton J, Mascha E, Abdel-Hafez MA, Thomas AJ Jr, Agarwal A. Relationship between ROS production, apoptosis and DNA denaturation in spermatozoa from patients examined for infertility. Hum Reprod. 2004; 19(1):129-38.

Oehninger S, Morshedi M, Weng SL, Taylor S, Duran H, Beebe $\mathrm{S}$. Presence and significance of somatic cell apoptosis markers in human ejaculated spermatozoa. Reprod Biomed Online 2003; 7(4):469-476.

Ricci G, Perticarari S, Boscolo R, Montico M, Guaschino S, Presani G. Semen preparation methods and sperm apoptosis: swim-up versus gradient-density centrifugation technique. Fertil Steril. 2009; 91(2):632-8.

Rougier N, Uriondo H, Papier S, Checa MA, Sueldo C, Alvarez Sedó C. Changes in DNA fragmentation during sperm preparation for ICSI over time. Fertil Steril (accepted) 2013.

Sakkas D, Moffatt O, Manicardi GC, Mariethoz E, Tarozzi N, Bizzaro D. Nature of DNA damage in ejaculated human spermatozoa and the possible involvement of apoptosis. Biol Reprod 2002; 66(4):1061-1067.

Sakkas D, Seli E, Bizzaro D, Tarozzi N, Manicardi GC. Abnormal spermatozoa in the ejaculate: abortive apoptosis and faulty nuclear remodelling during spermatogenesis. Reprod Biomed Online 2003; 7(4):428-432.

Saleh RA, Agarwal A. Oxidative stress and male infertility: from research bench to clinical practice. J Androl. 2002; 23(6):73752. Review.

Simon L, Brunborg G, Stevenson M, and col. Clinical significance of sperm DNA damage in assisted reproduction outcome. Hum Reprod 2010; 25(7):1594-608.

Simon L, Lewis SE. Sperm DNA damage or progressive motility: which one is the better predictor of fertilization in vitro? Syst Biol Reprod Med 2011; 57(3):133-8.

Singh NP, Muller $\mathrm{CH}$, Berger RE. Effects of age on DNA double-strand breaks and apoptosis in human sperm. Fertil Steril 2003; 80(6):1420-1430.

Speyer BE, Pizzey AR, Ranieri $M$, and col. Fall in implantation rates following ICSI with sperm with high DNA fragmentation. Hum Reprod 2010; 25(7):1609-18.

Steger K, Cavalcanti MC, Schuppe HC. Prognostic markers for competent human spermatozoa: fertilizing capacity and contribution to the embryo. Int J Androl 2011; 34(1):513-27.

Stevanato J, Bertolla RP, Barradas V, Spaine DM, Cedenho AP, Ortiz $\mathrm{V}$. Semen processing by density gradient centrifugation does not improve sperm apoptotic deoxyribonucleic acid fragmentation rates. Fertil Steril. 2008; 90(3):889-90.

World Health Organization. "WHO Laboratory Manual for the examination and processing of human semen" Cambridge: Cambridge University. Fifth Edition (2010).

Wu GJ, Chang FW, Lee SS, Cheng YY, Chen $\mathrm{CH}$, Chen IC. Apoptosis-related phenotype of ejaculated spermatozoa in patients with varicocele. Fertil Steril 2009;91(3):831-837.

Zhang XD, Chen MY, Gao Y, and col. The effects of different sperm preparation methods and incubation time on the sperm DNA fragmentation. Hum Fertil 2011; 14(3):187-91. 